\title{
The Role of Knowledge Management
}

\section{Infrastructure in Enhancing Job Satisfaction at Aqaba Five Star Hotels in Jordan}

\section{Ra'ed Masa'deh}

Management Information Systems Department, School of Business, The University of Jordan, Amman, Jordan

Email: r.masadeh@ju.edu.jo

How to cite this paper: Masa'deh, R. (2016) The Role of Knowledge Management Infrastructure in Enhancing Job Satisfaction at Aqaba Five Star Hotels in Jordan. Communications and Network, 8, 219-240. http://dx.doi.org/10.4236/cn.2016.84021

Received: August 10, 2016

Accepted: October 24, 2016

Published: October 27, 2016

Copyright $\odot 2016$ by author and Scientific Research Publishing Inc. This work is licensed under the Creative Commons Attribution International License (CC BY 4.0).

http://creativecommons.org/licenses/by/4.0/

\begin{abstract}
The aim of this research is to explore the role of Knowledge Management (KM) infrastructure (organizational culture, organizational structure and information technology) in enhancing job satisfaction at Aqaba five star hotels located in Jordan. A total of 216 questionnaires containing 33 items were used to collect information from the respondents. Multiple regression analysis was conducted to test the research hypotheses. Results of the current study revealed that there is a significant positive impact of KM infrastructure on job satisfaction and these results are in line with the results of the previous studies mentioned in the literature, and also revealed that the dimensions of KM infrastructure that has the highest effect on job satisfaction are organizational culture followed by information technology; whereas the variable of organizational structure has not significant impact on it. Results of T-test showed that there is no significant difference in the impact of KM infrastructure towards job satisfaction in favor of gender. In addition, results of ANOVA test found that there are significant differences in the impact of KM infrastructure on job satisfaction that can be attributed to age, educational level, and personal income.
\end{abstract}

\section{Keywords}

Knowledge Management Infrastructure, Job Satisfaction, Jordan

\section{Introduction}

Knowledge is what a knower knows and there is no knowledge without someone knowing it [1]. [2] emphasized that firms consider knowledge to be their most valuable and strategic resource, and confirmed that the more a firm knows about its customers, products, technologies, markets, and their linkages, the better it will perform. There- 
fore, since knowledge is involved in most activities in firms, it has become a primary factor in their success. In addition, firms need to manage their knowledge resources more efficiently to enhance performance and produce the biggest payoffs, and to obtain a competitive advantage [3]. Several researchers in the KM field emphasize the importance of knowledge. For instance, [4] in [5] offered numerous reasons to explain such values. First of all, firms are under huge pressure to stay ahead of competitors because of increased adaptability and process speed, as a result of the globalization of the economy. Also, there is increasing awareness of the value of specialized knowledge, as embodied in organizational processes and routines, in coping with the pressure of economic globalization. In addition, people are now better able to work with and learn from each other as a result of falling cost of networked computing.

Knowledge, its effective use, and the acquisition of new knowledge are considered the only way organizations can sustain a competitive advantage in today's highly competitive environment [6]. Researchers from various disciplines such as sociology, economics, and management sciences have agreed that knowledge has stolen the spotlight away from traditional resources. They further contend that managers and executives should place close attention to the management of knowledge [7]-[11]. Therefore, it has been recommended that managing knowledge should be at the basis of an organization's capability development effort, which ultimately leads to better business performance and creating value for the company's various stakeholders [6]. As such, knowledge management is regarded as a prerequisite for the improvement of productivity and flexibility of the organization [7].

By dissecting the term knowledge management into its origins, we end up with two concepts, "knowledge" and "Management". Management refers to the process of controlling, guiding, coordinating, and communicating interconnected actions, activities, and modes of knowing that are restricted by certain purposes, rules, and routines [12]. Various interpretations have been provided for the word "knowledge". Knowledge has been previously linked to terms such as data, information, intelligence, skills, expertise, ideas, and insights [13]. Such a link can be attributed to the traditional way of looking at knowledge where data is arranged to become information, then information is processed in the minds of individuals in which experiences and judgments are included resulting in the creation of knowledge. According to this, knowledge can be defined as the information understood by individuals and related to facts, procedures, concepts, interpretations, ideas, observations, and judgments. However, not every piece of information turns into knowledge, this relates to the fact individuals sometimes fail to understand the contextual meaning of the information, thereby keeping the information in its current form [14]. Knowledge can also be defined as a mix of experiences, values, contextual information, and expert insight that provides a foundation for evaluating and incorporating new experiences and information which is originated and applied in the minds of individuals [15].

An important notion to consider when managing knowledge is the kind of knowledge to be managed [16]. Knowledge can be divided into two categories: explicit and 
tacit knowledge [13]. Explicit knowledge refers to knowledge which can be transmitted in the form of formal and systematic languages [17]. It relates to what can be captured and shared through information technology [7]. Explicit knowledge is considered an important management tool that can be used in the manipulation of organizational knowledge. Such knowledge, usually exists in words, pictures, diagrams, computer codes, procedure manuals, and the like, that can be communicated to others in ways that are seen as formal and obvious [18]. Tacit knowledge refers to unarticulated knowledge that exists in the minds of people and is difficult to describe and transfer [16]. [19], (p. 167) defined tacit knowledge as "personal knowledge based on individual experience and influenced by perceptions and values". Researchers have reported that tacit knowledge includes lessons learned, know-how, judgments, rule of thumb, intuition [20], individual experience, skills, beliefs, values, and creative processes [14]. According to the literature, tacit knowledge is an important organizational resource as 42 percent of corporate knowledge resides in the minds of employees and that the successful accomplishment of tasks depends on tacit knowledge [16]. In order to improve organizational performance and create value, organizations should manage both tacit and explicit knowledge since they are mutually dependent on one another and reinforce each others' qualities [14]. Here, systematic and specific processes are used to acquire, organize, sustain, apply, share and renew both tacit and explicit knowledge [21] as tacit knowledge can be of vital importance to organizations when it is converted into explicit form and shared with others [22].

Knowledge management as a whole is considered much more complex in meaning than the terms management and knowledge alone [13]. Knowledge management can be defined as a formal, directed process of determining which information would benefit the company better, compared to others, and finding ways to make information readily available to those that need it [16]. [23] saw knowledge management as a way of creating, executing, transforming, and storing of the right knowledge that leads to the design of better policy, modification of action, and delivery of results. [24] referred to knowledge management as a set of procedures, infrastructures, technical and managerial tools used to create, share, and leverage knowledge within and around the organization. After a review of the literature, it can be noted that researchers and practitioners have defined knowledge management in terms of three trends: 1) work processes and activities where knowledge management comprises processes, systems, procedures, and instruments that support the identification, capturing, and leveraging of knowledge [25] [26]; 2) Technology infrastructure, which refers to the investment in information to codify, store, share, and disseminate specific types of knowledge beyond physical and time barriers in an easier and less expensive manner than done before [14]; 3) Behavioral norms and practices (Organizational culture) which reflects "a set of valid knowledge, created and shared by a group of people, to solve problems they face in their environment" [27] (p. 5).

The importance of knowledge management for organizations has been reported by many researchers over the years. [15] and [28] for example, suggested that knowledge 
management creates new capabilities for organizations, enables superior performance, encourages innovation, and enhances customer value. [29] supported this by stating that knowledge management stimulates innovation, improves services provided to customers, and helps organizations achieve business excellence by accumulating, improving the availability and accessibility, and effective use of knowledge. [14] also reported that managing knowledge well assists organizations in becoming flexible, responding quickly to changing conditions, becoming innovative, and improving decision making capacity and productivity. However, in order for knowledge management to be efficient and effective certain capabilities are required. [30] argued that resource-based capability consisting of technology, structure, and culture, in addition to knowledge-based capability, including expertise, learning and information, are needed for organizations to effectively and efficiently manage knowledge. In this study, the resource-based capabilities, also known as knowledge management infrastructure [31], will be investigated further as an important component of knowledge management.

The rest of this paper is organized as follows. It begins with the theoretical framework and previous studies about knowledge management infrastructure, as well as other previous studies links knowledge management infrastructure with job satisfaction. Then, the methodology in which the research theoretical model, hypotheses, population and sample, data collection and analysis methods, and the validity and reliability of the study are presented. It then provides the results and explanations which show the results of the data analysis of the research hypotheses and explanation of these results. The discussion and conclusion are then provided and areas for future research are also addressed.

\section{Theoretical Framework}

\subsection{Knowledge Management Infrastructure}

Knowledge management infrastructure capability refers to modular products and organizational designs that encourage knowledge management activities in an organization [32]. KM infrastructure can be classified into two major capabilities, technical and social infrastructure. Technical infrastructure includes physical, IT infrastructure, devices and components. Social infrastructure, on the other hand, includes culture, structure, and human resources [33]. As such, it can be noted that KM infrastructure provides the infrastructural environment, both IT and non-IT that supports knowledge management activities [14] [34]-[36]. Furthermore, organizations should strive to develop infrastructure capabilities not only in terms of hardware and software, but also in terms of culture, structure, people, and technology [33]. [37] supported this by indicating that organizations that utilize both technical and organizational infrastructures are more likely to implement successful knowledge management projects.

\subsubsection{Organizational Culture}

Organizational culture has been defined as the specific collection of values and norms that are shared by people and groups in an organization and that control the way they 
interact with each other and with stakeholders outside the organization [38]-[41]. Organizational culture not only defines the value and advantage of knowledge for organizations, it also influences the ability of employees to share knowledge [42]. It has been reported that organizational culture is crucial for knowledge sharing and team work [14] [43]. The reason behind this is that organizational culture is pivotal in encouraging interaction and collaboration between individuals that is necessary for the flow of knowledge. It also provides individuals with the ability to self-organize their personal knowledge to facilitate problem solving and the sharing of knowledge [44]. In addition, researchers have reported that one of the most significant elements of culture for knowledge sharing to consider is trust. High levels of trust reduce the reluctance of individuals to share knowledge and decrease the associated risk of losing competitiveness [33] [45]. Therefore, creating a culture that allows for easy access of knowledge should be at the top of management's agenda during the implementation stage of knowledge management [42]. However, this is easily said than done as aligning the culture of the organization with the goals of knowledge management is considered a complex process, especially in organizations characterized by hierarchical structures and bureaucratic controls [46].

\subsubsection{Organizational Structure}

The connection between organizational structure and knowledge sharing stems from the social aspect of organizations that includes hierarchy, density, and connectivity that links employees together thereby facilitating the exchange of knowledge. Here authors suggest that two aspects of organizational structure affect the flow of knowledge; formalization and centralization [35]. Centralization refers to the extent to which decision making and the right to evaluate activities are concentrated at the top of the organizational hierarchy [47]. Formalization relates to "formal rules and regulations that govern organizational activities and manage work relations" [33], (p. 4). Therefore, organizational structure is considered an important factor for facilitating the flow of knowledge in organizations through the use of organizational policies, processes, and systems of rewards and incentives that determine how knowledge is accessed and subsequently flows throughout the organization.

\subsubsection{Information Technology}

Technology infrastructure thus plays a pivotal role in an organization's knowledge management system in terms of creating and using new knowledge, and sharing existing knowledge by incorporating various technological platforms. While hardware, networking, and bandwidth elements of technology are important, they are not sufficient to perform the KM activities of sharing, storing, disseminating, and maintaining knowledge. Other tools are thus required, like social media, content repositories, and dynamic websites [48]. Although technology enhances the organization's ability to conduct knowledge management activities, as a single construct it is not sufficient on its own. Technology therefore requires the support of other KM enablers such as organizational culture, structure, and business strategy to ensure that the right knowledge is be- 
ing managed in the right way [14].

\subsection{Job Satisfaction}

Job satisfaction can be defined as the extent to which an employee like his/her job [49]. Job satisfaction can also be seen as the affective, cognitive, and evaluative reactions of individuals towards their jobs [50]-[52] suggested that job satisfaction reflects the gratification and sense of fulfillment one receives from doing their job. [53] defined job satisfaction as the collection of beliefs and feelings people have about their jobs. [54] referred to job satisfaction as the degree to which individuals accept their work and their relationship with others in the work environment. All in all job satisfaction relates to how people think, feel, and perceive their jobs [55], i.e. their attitudes towards different aspects such as work itself, level of pay, promotion opportunities, and satisfaction with co-workers.

Over the years, various researchers have attempted to determine and classify the factors affecting job satisfaction. Two perspectives have emerged regarding the determinants of job satisfaction. The content perspective approaches job satisfaction from the perspective of needs fulfillment. Studies advocating the content perspective include Maslow's needs hierarchy, Herzberg's two factor theory, ALderfer's ERG theory, and McCelelland's theory of needs. The process perspective focuses on the cognitive process leading to job satisfaction. Process theories include Vroom's expectancy theory, Adam's equity theory, behavior modification, and cognitive evaluation theory [56] [57]. Both content and process perspectives have reported a sea of factors related to job satisfaction. These factors can be grouped into two broad categories: demographic factors and environmental factors. Demographic factors relate to individual attributes and characteristics such as: gender, age, job-level, and work experience. Environmental factors refer to factors associated with the work itself or work environment such as salary, promotion, supervision, climate management, fairness of appraisal systems, and satisfaction with coworkers [57]. Other scholars have classified job satisfaction factors into intense and extrinsic factors. Intrinsic factors relate to the actual work individuals do in the organization. Such factors include variety, skill utilization, and autonomy. Extrinsic factors relate to aspects of the work environment such as pay, working conditions, and coworkers [56].

Measuring job satisfaction has always been a challenge for both researchers and managers. A gap has always existed in most methods between what real satisfaction is and measured satisfaction. Therefore, creating a measurement method that is free from bias is a major concern in organizational behavior studies. Several methodologies exist for measuring satisfaction. [58] evaluated a weighted model, [59] focused on the stability of the job descriptive index (JDI), [60] challenged the facet importance of job satisfaction, [61] assessed asymmetric effects in satisfaction formation, and [62] debated the scale of JDI [63]. In conclusion, job satisfaction can be seen as a crucial social phenomenon for organizations, as it leads to the provision of high quality performance by improving the cohesion and morale of individuals. It is also important as it is closely 
related to working behaviors such as productivity and efficiency. Here satisfied employees have the motivation to improve their work behaviors, whereas unsatisfied workers tend to behave less effectively [64].

\subsection{Knowledge Management Infrastructure and Job Satisfaction}

Some researchers (e.g. [10] [35] [41] [65]-[67]) emphasize the need for large firms to integrate their IT with their KM strategies and processes in order to survive in their highly competitive business environments. In terms of organizational culture, many studies have been conducted to examine the link between culture and job satisfaction. The results of the studies are, however, quite contradictory. Some researchers have stated that organizational culture is one of the most important antecedents of job satisfaction, thereby indicating a positive relationship between organizational culture and job satisfaction (see [68]-[70]).

Whereas other researchers, such as [71] have argued that job satisfaction and organizational culture are not related. Organizational structure has been suggested to affect employees' judgements and perceptions and in turn play a significant role in human resource issues [72]. Therefore, organizational behaviorists and human resource professionals have long debated the preferred way to structure the work environment to affect employee outcomes [73]. [74] examined the relationship between organizational structure and job satisfaction. The researchers found that the two dimensions of structure (specialization and formalization) positively affected job satisfaction and that centralization had a negative effect on job satisfaction. [73] indicated that the structure of academic departments is related to faculty members' outcomes. More specifically, faculty members working in organically structured departments have higher levels of job satisfaction compared to other structures. [72] also investigated the relationship between organizational structure and job satisfaction and found that the dimensions of structure (complexity, formalization, and centralization) explain only $32 \%$ of the variation in job satisfaction, indicating that other factors should be taken into consideration in explaining the variation in job satisfaction.

Given that technology is considered one of the most important knowledge management enablers within organizations [9] [35] [43] [75], its effect on job satisfaction should be invesitagetd. The importance of technology for job satisfaction has been resported by several researchers. [76], for example, found that work technology was positively and significantly related to job satisfaction. [34]'s study results also showed that the use of IT and organizational structure has a significant influence on job satisfaction. These findings are supported by [77] who revealed that the more a company invests in IT, the more satisfied its employees will be with their working conditions, their relationships with colleagues and personal job characteristics.

\section{Research Methodology}

This section provides the methodology applied in the current study. It consists of the research model, operational definitions of the study's independent and dependent va- 
riables, research hypotheses, besides data collection tool and research population and sample.

\subsection{Research Model}

The major elements of this research are established based on preceding literature, either theoretically or empirically. Indeed, this study used variables that are common in knowledge management literature. Figure 1 represents a model for the study that shows the independent variables within the construct of knowledge management infrastructure, and the dependent variable (job satisfaction), and the proposed relationship between them.

\subsection{Operational Definitions}

The current research considers three independent variables within the construct of knowledge management infrastructure, and one dependent variable (job satisfaction). Further, knowledge management infrastructure includes organizational culture, organizational structure, and information technology. Organizational culture is a system of shared values and beliefs that produces norms of behavior and establishes an organizational way of life. The successful implementation of knowledge management requires an organizational culture that encourages employees to create and share knowledge [78]. A multi-item indicator was built comprising six items, including values such as trust, confidence, cooperation, learning, and recognition of expertise [31] [78]-[80]. [31] identified organizational structure as the formal rules and authorities that exist within an organization. Organizational structure has multiple dimensions include centralization, formalization, in addition to the incentive system, which is needed to encourage knowledge creation and sharing. Accordingly, organizational structure will be measured through six items in the research questionnaire adapted from [31] [80]-[82]. [81] defined information technology as the degree to which knowledge management is supported by the use of IT. Information technology playing an important role in knowledge management, it allow packing up the knowledge, facilitating access to

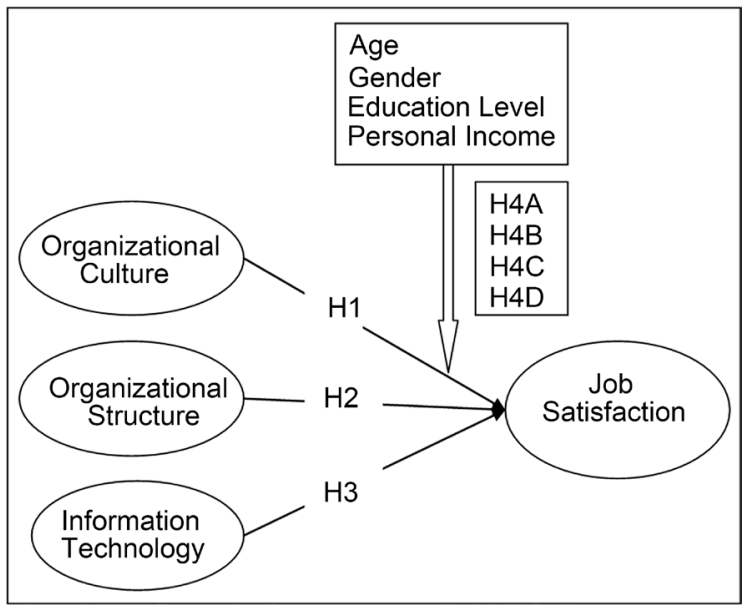

Figure 1. Research model. 
knowledge, and sharing knowledge. The knowledge management systems include two types of technology: communication technology, collaboration technology. Communication technology enables access to the required knowledge and facilitates communication among users in the firm. Collaboration technology provides required tools and applications to enhance collaboration in the workplace [83]. [84] add another dimension to measure IT infrastructure, which is End-User Focus and whether information systems and software are designed to be user-friendly. In this research six items are adapted from [30] [82] [84] [85]; to measure information and communication technology.

Job satisfaction in this research is defined as a construct of the degree to which the employee is satisfied and happy with the job [86], and validated by [41]. Job satisfaction is conceptualized as a combination of feelings about different dimensions of a job. Five dimensions provide separate measures of JS and consist of 14 items. These included being satisfied with pay and other compensation- 2 items, job security-2 items, peers and co-workers ("social")-3 items, supervision-3 items, and opportunities for development ("growth" satisfaction) 04 items. After measuring employees' satisfaction with different elements of a job, a composite score of the items is calculated as a measure of overall satisfaction.

\subsection{Research Hypotheses}

In order to test the research model of the impact of knowledge management infrastructure on job satisfaction, the study is hypothesized as follows:

$\mathrm{H1}$ : There is a statistically significant impact of organizational culture on job satisfaction.

$\mathrm{H} 2$ : There is a statistically significant impact of organizational structure on job satisfaction.

H3: There is a statistically significant impact of information technology on job satisfaction.

H4A: There is a significant difference in the impact of knowledge management infrastructure on job satisfaction due to gender.

H4B: There is a significant difference in the impact of knowledge management infrastructure on job satisfaction due to age.

H4C: There is a significant difference in the impact of knowledge management infrastructure on job satisfaction due to educational level.

H4D: There is a significant difference in the impact of knowledge management infrastructure on job satisfaction due to personal income.

\subsection{Population and Sampling}

Empirical data for this study was collected through paper-based survey in 5 star hotels located in Aqaba city in Jordan. Specifically, a survey questionnaire was used to gather data for hypotheses testing from staffs that are familiar with knowledge management activities. Thus, a judgment sampling technique was conducted. Before implementing the surveys, the instrument was reviewed by four lecturers who are specialized in the 
hotel management discipline in order to identify problems with wording, content, and question ambiguity. After some changes were made based on their suggestions, the modified questionnaire was piloted on five staffs that are familiar with the hotel's knowledge management systems. Based on the feedback of this pilot study, minor edits were introduced to the survey questions, and the questionnaires were distributed to the participants. As per ethics policies, all potential participants were briefed about the nature of the work and were requested to provide explicit approval. 216 questionnaires were returned and considered for statistical analysis. The questionnaire consisted of two sections; the first section in questionnaire presents general personal information about a respondent such as the gender, age, educational level, and personal income. The second section includes questions to measure the independent and dependent variables based on their operational definitions.

\section{Data Analysis and Results}

In order to explore the impact of knowledge management infrastructure on job satisfaction, in which KM infrastructure variables have been measured using 5-points Likert scale that varies between not agree at all $=1$ and totally agree $=5$; and using 5 -points $\mathrm{Li}$ kert scale that varies between strongly dissatisfied $=1$ and strongly satisfied $=5$ for job satisfaction. Reliability and validity analyses was conducted, descriptive analysis was used to describe the characteristic of sample and the respondent to the questionnaires besides the independent and dependent variables. Also, multiple regression analysis was employed to test the research hypotheses beside ANOVA and T-test ones.

\subsection{Validity and Reliability}

Validity and reliability are two important measures to determine the quality and usefulness of the primary data. Validity is about accuracy and whether the instrument measures what it is intended to measure while reliability is about precision; it is used to check the consistency and stability of the questionnaire. Indeed, the researchers depended on scales and items that were previously developed and used by other researchers with similar interest. Also a draft of the questionnaire was formulated, and then it was reviewed by five academic lecturers-who have a sufficient knowledge and experience in this scope-to insure that each item is measuring what is intended to be measured, and to avoid the ambiguity and complexity in the phrasing of questions. The reliability of the instrument was measured by the Cronbach's alpha coefficient. Further, some scholars [87] suggested that the values of all indicators or dimensional scales should be above the recommended value of 0.60 . Table 1 represents the results of Cranach's alpha for the independent and dependent variables. Cronbach's alpha coefficients of all the tested variables are above 0.60 which suggesting the composite measure is reliable.

\subsection{Respondents Demographic Profile}

As indicated in Table 2, the demographic profile of the respondents for this study 
showed that they are typically males, hold bachelor degrees, and $69.7 \%$ of the respondents have more than five years experience.

\subsection{Descriptive Analysis}

In order to describe the responses and thus the attitude of the respondents toward each question they were asked in the survey, the mean and the standard deviation were estimated. While the mean shows the central tendency of the data, the standard deviation measures the dispersion which offers an index of the spread or variability in the data [88]. In other words, a small standard deviation for a set of values reveals that these values are clustered closely about the mean or located close to it; a large standard deviation indicates the opposite. The level of each item was determined by the following formula: (highest point in Likert scale-lowest point in Likert scale)/the number of the levels used $=(5-1) / 5=0.80$, where $1-1.80$ reflected by "very low", $1.81-2.60$ reflected by "low", 2.61 - 3.40 reflected by "moderate", 3.41 - 4.20 reflected by "high", and 4.21 - 5 reflected by "very high". Then the items were being ordered based on their means. Table 3 and Table 4 show the results.

Table 1. The Cronbach's alpha coefficients of study variables.

\begin{tabular}{ccc}
\hline Variables & Number of items & Cronbach alpha \\
\hline Organizational culture & 6 & 0.955 \\
Organizational structure & 6 & 0.772 \\
Information technology & 7 & 0.932 \\
Job satisfaction & 14 & 0.838 \\
\hline
\end{tabular}

Table 2. Description of the respondents' demographic profiles.

\begin{tabular}{cccc}
\hline Category & Category & Frequency & Percentage \% \\
\hline \multirow{2}{*}{ Gender } & Male & 134 & 62.0 \\
& Female & 82 & 38.0 \\
& Total & 216 & 100 \\
& 18 years - less than 25 & 55 & 25.5 \\
Age & 25 years - less than 30 & 67 & 31.0 \\
& 30 years - less than 40 & 82 & 38.0 \\
& More than 40 years old & 12 & 5.5 \\
& Total & 216 & 100 \\
& Less than high school & 35 & 16.2 \\
& High school & 65 & 31.1 \\
Education level & Diploma & 32 & 14.8 \\
& Bachelor & 49 & 22.7 \\
& Master & 18 & 8.3 \\
& Doctorate & 17 & 7.9 \\
& Total & 216 & 100 \\
& Less than 750 & 42 & 19.4 \\
& 750 - less than 1500 & 103 & 47.7 \\
& More than 1500 & 71 & 32.9 \\
& Total & 216 & 100 \\
\hline
\end{tabular}


Table 3. Overall mean and standard deviation of the study's variables.

Type of variable
Independent variables

Dependent variable

Variables
KM infrastructure
Organizational culture
Organizational structure
Information technology

Job satisfaction

$\begin{array}{cc}\text { Mean } & \text { Standard deviation } \\ \mathbf{3 . 8 1 8 3} & \mathbf{0 . 6 2 7} \\ 3.7965 & 0.512 \\ 3.9606 & 0.984 \\ 3.7230 & 0.652 \\ \mathbf{3 . 7 7 1 2} & \mathbf{0 . 7 7 9}\end{array}$

$\begin{array}{lc}\text { Level } & \text { Order } \\ \text { High } & \\ \text { High } & 2 \\ \text { High } & 1 \\ \text { High } & 3 \\ \text { High } & \end{array}$

Table 4. Mean and standard deviation of the study's variables.

\begin{tabular}{|c|c|c|c|c|}
\hline Organizational culture & Mean & SD & Level & Order \\
\hline Employees in this hotel are willing to support and help each other. & 3.91 & 1.098 & High & 4 \\
\hline Employees in this hotel are generally trust worthy. & 4.05 & 1.017 & High & 1 \\
\hline Employees in this hotel are encouraged to ask others for assistance when needed. & 3.94 & 1.241 & High & 2 \\
\hline Employees in this hotel understand the importance of knowledge sharing to corporate success. & 3.89 & 1.210 & High & 5 \\
\hline The benefits of sharing knowledge outweigh the costs. & 4.05 & 1.077 & High & 1 \\
\hline Employees in this hotel are encouraged to participate in seminars and group discussion. & 3.93 & 0.854 & High & 3 \\
\hline Employees in this hotel can make decisions without approval from their supervisor. & 3.83 & 0.976 & High & 2 \\
\hline Employees in this hotel can easily obtain the knowledge they need, and not limited by sub-group. & 3.70 & 1.163 & High & 3 \\
\hline In this hotel there are many activities that are not covered by some formal procedures. & 3.66 & 0.916 & High & 4 \\
\hline In this hotel rules and procedures are typically written. & 3.56 & 0.775 & High & 6 \\
\hline This hotel has a standardized reward system for sharing knowledge. & 3.63 & 0.864 & High & 5 \\
\hline We have easy computer access to the information we need to do our jobs. & 3.89 & 0.896 & High & 1 \\
\hline In this hotel, IT software and applications are used to support collaborative work (e.g., video conferencing systems). & 3.77 & 0.904 & High & 3 \\
\hline Information system and software in this hotel are easy to use and have a user-friendly interface. & 3.63 & 0.841 & High & 6 \\
\hline There is continuous update of the hotels' software and hardware. & 3.72 & 0.933 & High & 4 \\
\hline This hotel has preventive systems to guard against inefficient and inappropriate knowledge application. & 3.69 & 0.994 & High & 5 \\
\hline Pay & Mean & SD & Level & Order \\
\hline The amount of pay and fringe benefits I receive. & 3.96 & 0.878 & High & 1 \\
\hline $\begin{array}{l}\text { The degree to which I am fairly paid for what I contribute to } \\
\text { this hotel. }\end{array}$ & 3.93 & 0.843 & High & 2 \\
\hline Job Security & Mean & SD & Level & Order \\
\hline The amount of job security I have. & 3.84 & 0.691 & High & 1 \\
\hline The degree of respect and fair treatment I receive from my supervisor. & 3.54 & 1.020 & High & 3 \\
\hline The amount of support and guidance I receive from my supervisor. & 3.84 & 0.791 & High & 1 \\
\hline The overall quality of the supervision I receive in my work. & 3.69 & 0.915 & High & 2 \\
\hline Growth Satisfaction & Mean & SD & Level & Order \\
\hline The amount of personal growth and development I get in doing my job. & 4.04 & 0.695 & High & 2 \\
\hline The feeling of worthwhile accomplishment I get from doing my job. & 3.99 & 0.860 & High & 3 \\
\hline The amount of independent thought and action I can exercise in my job. & 3.81 & 0.958 & High & 4 \\
\hline The amount of challenge in my job. & 4.08 & 0.831 & High & 1 \\
\hline
\end{tabular}


As presented in Table 3, data analysis results have shown that knowledge management infrastructure is applied to a great extent in Aqaba five star hotels in Jordan in which the mean score is 3.8183 . This indicates an indicator on the importance of knowledge management infrastructure, and such high level of presentation denotes a positive attitude regarding the infrastructure of knowledge management. In addition, job satisfaction found to be high as well. This advocates that Jordanian five star hotels located in Aqaba city are currently engaging in job satisfaction activities to maintain competitive advantages. Table 4 demonstrates the mean scores for knowledge management infrastructure, and job satisfaction items.

\subsection{Hypotheses Testing Results}

The current research is mainly seeking to investigate the impact of knowledge management infrastructure (organizational culture, organizational structure, and information technology) on job satisfaction in Aqaba five star hotels in Jordan. Consequently, in order to test the hypotheses developed for this study, multiple regression technique was used. Further, the level of significance ( $\alpha$-level) was chosen to be 0.05 and the probability value ( $\mathrm{p}$-value) obtained from the statistical hypotheses test is considered to be the decision rule for rejecting the null hypotheses [89]. If the p-value is less than or equal to $\alpha$-level, the null hypothesis will be rejected and the alternative hypothesis will be supported. However, if the p-value is greater than the $\alpha$-level, the null hypothesis cannot be rejected and the alternative hypothesis will not be supported. In addition, normality of the independent variables and the absence of multi co-linearity problem (a case of multiple regression in which the independent variables are themselves highly correlated) were checked. According to [90], most of the values should be inside the adequate ranges for normality (i.e. -1.0 to +1.0 ). For this purpose, skewness and Variance Inflation Factor (VIF) were investigated; Table 5 includes the results.

As can be figured out from Table 5, the skewness values were within the normal values $(1.0$ to +1.0$)$ suggesting that the data of the independent variables is normal. The VIF values were less than the critical value (10) which is most common among the most studies, suggesting no multi co-linearity problem among the independent variables. However, the results of testing the three hypotheses on the impact of knowledge management infrastructure (organizational culture, organizational structure, and information technology) on job satisfaction are demonstrated in Table 6.

Table 5. Skewness and VIF for the independent variables.

\begin{tabular}{cccc}
\hline Variables & Tolerance & VIF & Skewness \\
\hline Organizational culture & 0.571 & 1.751 & -0.65 \\
Organizational structure & 0.396 & 2.525 & -0.19 \\
Information technology & 0.612 & 1.635 & -0.69 \\
\hline
\end{tabular}


Table 6. Result for the study model (b).

\begin{tabular}{cccccccc}
\hline Variable & $\mathbf{r}$ & $\mathbf{R}^{2}$ & $\mathbf{f}$ & $\mathbf{S i g}(\mathbf{f})$ & $\boldsymbol{\beta}$ & $\mathbf{t}$ & $\operatorname{Sig}(\mathbf{t})$ \\
\hline Organizational culture & & & & & 0.372 & 4.705 & 0.000 \\
Organizational structure & 0.494 & 0.244 & 22.769 & $0.000 \mathrm{a}$ & 0.117 & 1.236 & 0.218 \\
Information technology & & & & & 0.192 & 2.322 & 0.041 \\
\hline
\end{tabular}

Refer to Table 6 the multiple correlation coefficient $\mathrm{R}=0.494$ indicates that there is a medium positive correlation between knowledge management infrastructure (organizational culture, organizational structure, and information technology) and job satisfaction. The adjusted $\mathrm{R}^{2}$ indicated the generalizability of the model. It allows us to generalize the results taken from the respondents to the whole population. In this case it equals 0.244 . The results showed that F-ratio for these data is equal to 22.769 , which is statistically significant at $\mathrm{p}<0.05$. Therefore, we conclude that there is a statistically significant effect of knowledge management infrastructure on job satisfaction.

The $\beta$ indicates the individual contribution of each predictor (independent variable) to the model, if other predictors are held constant. Table 6 shows the standardized coefficients for each knowledge management infrastructure dimensions. The value of $\beta$ for organizational culture and information technology are $0.372,0.192$ respectively, which are positive and significant at $\mathrm{p} \leq 0.05$; thus $\mathrm{H} 1$ and $\mathrm{H} 3$ were supported. While for organizational structure, the value of $\beta$ is 0.117 , which a small value compared with other predictors and not significant at $\mathrm{p} \leq 0.05$; thus $\mathrm{H} 2$ was not supported. The level of effect of these variables depends on the $\beta$ value, the higher $\beta$ value the higher effect on dependent variable. We can infer from the values of beta that the variable that has the highest contribution in the model is organizational culture, followed by information technology. The variable organizational structure does not have a significant effect on job satisfaction.

Hypotheses $\mathrm{H} 4 \mathrm{~A}, \mathrm{H} 4 \mathrm{~B}, \mathrm{H} 4 \mathrm{C}$, and $\mathrm{H} 4 \mathrm{D}$ argued that there is a significant difference in the impact of knowledge management infrastructure on job satisfaction due to gender, age, educational level, and personal income. Independent Samples T-test was employed in order to investigate if there any significant differences in the impact of knowledge management infrastructure on job satisfaction that can be attributed to gender. Also, ANOVA test was employed to examine if there any significant differences in the impact of knowledge management infrastructure on job satisfaction that can be attributed to age, educational level, and personal income. Results of T-test, shown in Table 7, indicated that there is a significant difference in the impact of knowledge management infrastructure on job satisfaction that can be attributed to gender. In addition, results of ANOVA test, shown in Table 8, Table 9, and Table 10, indicated that there are significant differences in the impact of knowledge management infrastructure on job satisfaction in favor of age, educational level, and personal income.

\section{Discussion and Conclusions}

This study aimed to identify the role of KM infrastructure (organizational culture, or- 
ganizational structure, and information technology) in enhancing job satisfaction at Aqaba five star hotels located in Jordan. The results found that knowledge management infrastructure is applied in the studied five star hotels in Jordan. Furthermore, data analysis results have shown that job satisfaction is effectively applied as well. This high level of application reflects a positive attitude toward employees' job satisfaction. Our results also indicate that Aqaba five star hotels in Jordan give careful attention to job satisfaction-related dimensions; they focus on being satisfied with pay and other compensation, job security, social impacts, supervision, and opportunities for development. Moreover, the results indicated a positive effect of organizational culture and information technology on job satisfaction; whereas no statistically significant effect found of organizational structure on job satisfaction. Moreover, the results of T-test indicated that there is no significant difference in the impact of KM infrastructure towards job satisfaction in favor of gender. Also, results of ANOVA test found that there are significant differences in the impact of KM infrastructure on job satisfaction that can be attributed to age, educational level, and personal income.

Table 7. T-test of the impact of knowledge management infrastructure on job satisfaction attributed to gender.

\begin{tabular}{ccccccccccc}
\hline & \multicolumn{3}{c}{ Male } & \multicolumn{3}{c}{ Female } & T & df & Sig. \\
\cline { 2 - 8 } & Nariables & Mean & Std. Dev. & N & Mean & Std. Dev. & & & \\
\hline $\begin{array}{c}\text { Organizational } \\
\text { Effectiveness }\end{array}$ & 134 & 3.7063 & 0.51607 & 82 & 3.9437 & 0.47458 & 3.450 & 182.455 & 0.001 \\
\hline
\end{tabular}

Table 8. ANOVA Analysis of impact of knowledge management infrastructure on job satisfaction attributed to age.

\begin{tabular}{ccccccc}
\hline Variables & & Sum of Squares & Df & Mean Square & F & Sig. \\
\hline & Between Groups & 25.831 & 3 & 8.610 & 59.460 & 0.000 \\
$\begin{array}{c}\text { Organizational } \\
\text { Effectiveness }\end{array}$ & Within Groups & 30.700 & 212 & 0.145 & & \\
& Total & 56.531 & 215 & & \\
& & & & & \\
\hline
\end{tabular}

Table 9. ANOVA Analysis of impact of knowledge management infrastructure on job satisfaction attributed to educational level.

\begin{tabular}{ccccccc}
\hline Variables & & Sum of Squares & Df & Mean Square & F & Sig. \\
\hline & Between Groups & 36.307 & 5 & 7.261 & 75.404 & 0.000 \\
$\begin{array}{c}\text { Organizational } \\
\text { Effectiveness }\end{array}$ & Within Groups & 20.223 & 210 & 0.096 & \\
& Total & 56.531 & 215 & & \\
\hline
\end{tabular}


Table 10. ANOVA Analysis of impact of knowledge management infrastructure on job satisfaction attributed to personal income.

\begin{tabular}{ccccccc}
\hline Variables & & Sum of Squares & Df & Mean Square & F & Sig. \\
& Between Groups & 13.090 & 2 & 6.545 & 32.093 & 0.000 \\
Organizational & Within Groups & 43.440 & 213 & 0.204 & & \\
Effectiveness & Total & 56.531 & 215 & & & \\
& & & & & \\
\hline
\end{tabular}

The first hypothesis stated that there is a statistically significant impact of organizational culture on job satisfaction. This result is consistent with the result of [91] that organizational culture had a significant effect on job satisfaction. This result is also supported by a number of studies showing that job satisfaction can be enhanced by organizational culture (See [68]-[70]). [41] found that emotional intelligence in terms of perception and appraisal of emotions, facilitating thinking with emotions, understanding emotions, and regulation and management of emotions can be used to predict job satisfaction. Consequently, the understanding of emotional intelligence theory and its applications can be promoted for managerial and human resource practices in public sector organizations.

The second hypothesis argued that there is a statistically significant impact of organizational structure on job satisfaction. This result is supported by the findings of [71], who found that job satisfaction and organizational culture are not related. Also, [78] argued that centralized organizations restrict the contribution that employees can make in performing their work, restrict knowledge sharing, and suppresses innovative solutions. However, this is against other researchers findings (e.g. [72]-[74]) who emphasized the impact of organizational structure in terms of complexity, formalization, and centralization on job satisfaction.

The third hypothesis stated that there is a statistically significant impact of information technology on job satisfaction. This result is agreed with [76] and [34] findings, as they found a high correlation between work technology and job satisfaction. Also, this result is supported by the findings of [77], who revealed that the more a company invests in IT, the more satisfied its employees and in turn increased job satisfaction characteristics. [92] stressed the importance of information and communication technology tools to innovation. The researchers found that information and communication technology can support knowledge management processes, which in turn promote flow of knowledge into the organization, which assist organizations realize their innovation potential.

The implications of this research should be addressed in light of the study's limitations that future research should address. The first limitation is related to the study instrument, the study used closed-ended questionnaire items to measure the effect of knowledge management infrastructure on job satisfaction. This type of question is easier and quicker for the respondent to complete and simpler for data analysis; however, it limited the responses because the participants could not make any inquiry or explain their answers in more depth. However, the second limitation of the study was the poor 
responsiveness of the hotels due to privacy issues; the hotels refused to participate in the study although it included general questions that did not affect their privacy. The third limitation is related to the participants of the study. In this context, there is a chance that some participants might respond positively as they want to provide a positive image about their hotels, consequently, indepth interviews are needed for future research. The fourth limitation is the use of judgment sampling, which is may not representative of the population, and this will affect the generalizability of the findings. Indeed, in connection to this study, knowledge management infrastructure explained $24.4 \%$ of the variations in job satisfaction; future researches and studies should focus on studying and investigating other factors that may enhance employees' job satisfaction. Also, because of the conflicting results regarding the impact of organizational structure on job satisfaction, further research is needed to explore this relationship. Finally, this study was applied on five star hotels in Aqaba city in Jordan; therefore, the finding cannot be generalized to other sector of industries or in other countries.

\section{References}

[1] Fahey, L. and Prusak, L. (1998) The Eleven Deadliest Sins of Knowledge Management. California Management Review, 40, 265-276. http://dx.doi.org/10.2307/41165954

[2] Zack, M. (1999) Developing a Knowledge Strategy. California Management Review, 41, 125-144. http://dx.doi.org/10.2307/41166000

[3] Meso, P. and Smith, R. (2000) A Resource-Based View of Organizational Knowledge Management Systems. Journal of Knowledge Management, 4, 224-234. http://dx.doi.org/10.1108/13673270010350020

[4] Prusak, L. (1999) Enemies and Enabler of KM. In: Chatzkell, J., Ed., Enterprise Intelligence World Summit: Annual Knowledge Conference and Exposition.

[5] Myers, P. (1996) Knowledge Management and Organizational Design. Butterworth-Heinemann, Oxford.

[6] Schiuma, G., Ordonez De Pablos, P. and Spender, J.C. (2007) Intellectual Capital and Company's Value Creation Dynamics. International Journal of Learning and Intellectual Capital, 4, 331-341.

[7] Maertensson, M. (2000) A Critical Review of Knowledge Management as a Management Tool. Journal of Knowledge Management, 4, 204-216.

http://dx.doi.org/10.1108/13673270010350002

[8] Masa'deh, R., Obeidat, B., Al-Dmour, R. and Tarhini, A. (2015) Knowledge Management Strategies as Intermediary Variables between IT-Business Strategic Alignment and Firm Performance. European Scientific Journal, 11, 344-368.

[9] Masa'deh, R., Tarhini, A., Al-Dmour, R. and Obeidat, B. (2015) Strategic IT-Business Alignment as Managers' Exploitative Strategies. European Scientific Journal, 11, 437-457.

[10] Shannak, R., Masa'deh, R. and Akour, M. (2012) Knowledge Management Strategy Building: Literature Review. European Scientific Journal, 8, 143-168.

[11] Shannak, R., Obeidat, B. and Masa'deh, R. (2012) Culture and the Implementation Process of Strategic Decisions in Jordan. Journal of Management Research, 4, 257-281.

http://dx.doi.org/10.5296/jmr.v4i4.2160

[12] Rechberg, I.D.W. and Syed, J. (2014) Appropriation or Participation of the Individual in 
Knowledge Management. Management Decision, 52, 426-445.

http://dx.doi.org/10.1108/MD-04-2013-0223

[13] Gao, F., Li, M. and Clarke, S. (2008) Knowledge, Management, and Knowledge Management in Business Operations. Journal of Knowledge Management, 12, 3-17.

http://dx.doi.org/10.1108/13673270810859479

[14] Chen, Q. (2011) Towards the Application Framework of Innovation-Based Knowledge Management System with Information Technology. In: Lin, S. and Huang, X., Eds., Advances in Computer Science, Environment, Ecoinformatics, and Education, Springer, Berlin, 407-412. http://dx.doi.org/10.1007/978-3-642-23357-9 72

[15] Gharakhani, D. and Mousakhani, M. (2012) Knowledge Management Capabilities and SMEs' Organizational Performance. Journal of Chinese Entrepreneurship, 4, 35-49. http://dx.doi.org/10.1108/17561391211200920

[16] Singh, S.K. (2008) Role of Leadership in Knowledge Management: A Study. Journal of Knowledge Management, 12, 3-15. http://dx.doi.org/10.1108/13673270810884219

[17] Nonaka, I., Krogh, G. and Voelpel, S. (2006) Organizational Knowledge Creation Theory: Evolutionary Paths and Future Advances. Organization Studies, 27, 1179-1208. http://dx.doi.org/10.1177/0170840606066312

[18] Dyck, B., Starke, F.A., Mischke, G.A. and Mauws, M. (2005) Learning to Build a Car: An Empirical Investigation of Oragnizational Learning. Journal of Management Studies, 42, 387-416. http://dx.doi.org/10.1111/j.1467-6486.2005.00501.x

[19] Noe, R.A. (2002) Employee Training and Development. McGraw-Hill Companies, Inc., New York.

[20] Bollinger, A.S. and Smith, R.D. (2001) Managing Organizational Knowledge as a Strategic Asset. Journal of Knowledge Management, 5, 8-18. http://dx.doi.org/10.1108/13673270110384365

[21] Bhirud, S., Rodrigues, L. and Desai, P. (2005) Knowledge Sharing Practices in KM: A Case Study in Indian Software Subsidiary. Journal of Knowledge Management Practices, 2, 8390.

[22] Frappaolo, C. (2006) Knowledge Management. Capstone Publishing Ltd., Southern Gate Chichester, West Sussex.

[23] Horwitch, M. and Armacost, R. (2002) Helping Knowledge Management Be All It Can Be. Journal of Business Strategy, 23, 26-31. http://dx.doi.org/10.1108/eb040247

[24] Bounfour, A. (2003) The Management of Intangibles: The Organization's Most Valuable Assets. Routledge, London. http://dx.doi.org/10.4324/9780203465035

[25] Carvalho, R.B. and Ferreira, M.A.T. (2001) Using Information Technology to Support Knowledge Conversion Processes. Information Research, 7, 421-458.

[26] Milam, J. (2005) Organizational Learning through Knowledge Workers and Infomediaries. New Directions for Higher Education, 131, 61-73. http://dx.doi.org/10.1002/he.187

[27] Pauleen, D.J., Wu, L. and Dexter, S. (2007) Exploring the Relationship between National and Organizational Culture, and Knowledge Management. In: Pauleen, D.J., Ed., CrossCultural Perspectives on Knowledge Management, Libraries Unlimited, Westport, 3-19.

[28] Obeidat, B., Al-Suradi, M., Masa'deh, R. and Tarhini, A. (2016) The Impact of Knowledge Management on Innovation: An Empirical Study on Jordanian Consultancy Firms. Management Research Review, 39.

[29] Demchig, B. (2015) Knowledge Management Capability Level Assessment of the Higher Education Institutions: Case Study from Mongolia. Procedia-Social and Behavioral Sciences, 
174, 3633-3640. http://dx.doi.org/10.1016/j.sbspro.2015.01.1082

[30] Aujirapongpan, S., Vadhanasindhu, P., Chandrachai, A. and Cooparat, P. (2010) Indicators of Knowledge Management Capability for KM Effectiveness. VINE, 40, 138-203. http://dx.doi.org/10.1108/03055721011050677

[31] Gold, A., Malhotra, A. and Segars, A. (2001) Knowledge Management: An Organizational Capabilities Perspective. Journal of Management Information Systems, 18, 185-214.

[32] Smith, T.A. (2006) Knowledge Management and Its Capabilities Linked to the Business Strategy for Organizational Effectiveness. Unpublished PhD Dissertation, Nova Southeastern University, Fort Lauderdale.

[33] Kushwaha, P. and Rao, M.K. (2015) Integrative Role of KM Infrastructure and KM Strategy to Enhance Individual Competence: Conceptualizing Knowledge Process Enablement. VINE, 45, 376-396. http://dx.doi.org/10.1108/vine-02-2014-0014

[34] Albaz, M.F.M. (2014) The Impact of Information Technology and Organizational Structure on Job Satisfaction among Academic Staff at Al-Azhar University in Palestine. Unpublished Master Thesis, Universiti Utara Malaysia, Kedah.

[35] Kanaan, R., Masa'deh, R. and Gharaibeh, A. (2013) The Impact of Knowledge Sharing Enablers on Knowledge Sharing Capability: An Empirical Study on Jordanian Telecommunication Firms. European Scientific Journal, 9, 237-258.

[36] Masa'deh, R., Shannak, R., Maqableh, M. and Tarhini, A. (2016) The Impact of Knowledge Management on Job Performance in Higher Education: The Case of the University of Jordan. Journal of Enterprise Information Management, 29.

[37] Davenport, T., Delong, D. and Beers, M. (1998) Successful Knowledge Management Projects. Sloan Management Review, 39, 43-57.

[38] Al-Azmi, N., Al-Lozi, M., Al-Zu’bi, Z., Dahiyat, S. and Masa'deh, R. (2012) Patients' Attitudes toward Service Quality and its Impact on their Satisfaction in Physical Therapy in KSA Hospitals. European Journal of Social Sciences, 34, 300-314.

[39] Alkalha, Z., Al-Zu'bi, Z., Al-Dmour, H., Alshurideh, M. and Masa'deh, R. (2012) Investigating the Effects of Human Resource Policies on Organizational Performance: An Empirical Study on Commercial Banks Operating in Jordan. European Journal of Economics, Finance and Administrative Sciences, 51, 44-64.

[40] Masa'deh, R. and Shannak, R. (2012) Intermediary Effects of Knowledge Management Strategy and Learning Orientation on Strategic Alignment and Firm Performance. Research Journal of International Studies, 24, 112-128.

[41] Vratskikh I., Masa'deh, R., Al-Lozi, M. and Maqableh, M. (2016) The Impact of Emotional Intelligence on Job Performance via the Mediating Role of Job Satisfaction. International Journal of Business and Management, 11, 69-91. http://dx.doi.org/10.5539/ijbm.v11n2p69

[42] Yeh, Y.J., Lai, S.-Q. and Ho, C.-T. (2006) Knowledge Management Enablers: A Case Study. Industrial Management \& Data Systems, 106, 793-810. http://dx.doi.org/10.1108/02635570610671489

[43] Masa'deh, R., Gharaibeh, A., Tarhini, A. and Obeidat, O. (2015) Knowledge Sharing Capability: A Literature Review. Proceedings of the 4th Scientific \& Research Conference on New Trends in Business, Management and Social Sciences (COES\&RJ-TK15/1), Istanbul, Turkey, 19-20 September 2015, 1-16.

[44] Sandhawalia, B.S. and Dalcher, D. (2011) Developing Knowledge Management Capabilities: A Structured Approach. Journal of Knowledge Management, 15, 313-328. http://dx.doi.org/10.1108/13673271111119718

[45] Masa'deh, R., Obeidat, B. and Tarhini, A. (2016) A Jordanian Empirical Study of the Asso- 
ciations among Transformational Leadership, Transactional Leadership, Knowledge Sharing, Job Performance, and Firm Performance: A Structural Equation Modelling Approach. Journal of Management Development, 35, 681-705. http://dx.doi.org/10.1108/JMD-09-2015-0134

[46] Dutta, B. and Madalli, P. (2015) Trends in Knowledge Modelling and Knowledge Management: An Editorial. Journal of Knowledge Management, 19, 1-3. http://dx.doi.org/10.1108/JKM-10-2014-0442

[47] Lee, H. and Choi, B. (2003) Knowledge Management Enablers, Processes, and Organizational Performance: An Integrative View and Empirical Examination. Journal of Management information Systems, 20, 179-228.

[48] Maqableh, M., Rajab, L., Quteshat, W., Masa'deh, R., Khatib, T. and Karajeh, H. (2015) The Impact of Social Media Networks Websites Usage on Students' Academic Performance. Communications and Network, 7, 159-171. http://dx.doi.org/10.4236/cn.2015.74015

[49] Abu Raddaha, A.H., Alasad, J., Albikawi, Z.F., Batarseh, K.S., Realat, E.A., Saleh, A.A. and Froelicher, E.S. (2012) Jordanian Nurses' Job Satisfaction and Intention to Quit. Leadership in Health Services, 25, 216-231. http://dx.doi.org/10.1108/17511871211247651

[50] Bilimoria, D., Perry, S.R., Liang, X., Stoller, E.P., Higgins, P. and Taylor, C. (2006) How do Female and Male Faculty Members Construct Job Satisfaction? The Roles of Perceived Institutional Leadership and Mentoring and their Mediating Processes. Journal of Technology Transfer, 31, 355-365. http://dx.doi.org/10.1007/s10961-006-7207-z

[51] Greenberg, J. and Baron, R.A. (2003) Behavior in Organizations: Understanding and Managing the Human Side of Work. 18th Edition, Prentice-Hall, Upper Saddle River.

[52] Griffin, R. and Moorhead, G. (2007) Organizational Behavior: Managing People and Organizations. 18th Edition, Houghton Mifflin Company, Boston.

[53] George, J.M. and Jones, G.R. (2008) Understanding and Managing Organizational Behavior. 5th Edition, Pearson Prentice-Hall, Upper Saddle River.

[54] Bahnase, F. (2011) Job Satisfaction for Workers from the Perspective of Social Service. House of Loyalty for World Publication, Alexandria.

[55] Spector, P.E. (1997) Job Satisfaction: Application, Assessment, Causes, and Consequences. Sage Publications Ltd., UK.

[56] AL-Ma'seb, H.B. and AL-Gaoud, E.R. (2015) Job Satisfaction among Kuwaiti Social Workers. Journal of the Gulf and Arabian Peninsula Studies, 152, 17-33.

[57] Abdullah, N.H., Shamsuddin, A., Wahab, E. and Hamid, N.A.A. (2014) The Relationship between Organizational Culture and Product Innovativeness. Procedia-Social and Behavioral Sciences, 129, 140-147. http://dx.doi.org/10.1016/j.sbspro.2014.03.659

[58] Quinn, R.P. and Mangione, T.W. (1973) Evaluating Weighted Models of Measuring Job Satisfaction: A Cinderella Story. Organizational Behavior and Human Performance, 10, 1-23. http://dx.doi.org/10.1016/0030-5073(73)90002-0

[59] Schneider, B. and Dachler, H.P. (1978) A Note on the Stability of the Job Descriptive Index. Journal of Applied Psychology, 63, 650-653. http://dx.doi.org/10.1037/0021-9010.63.5.650

[60] Furnham, A., Petrides, K.V., Jackson, C.J. and Cotter, T. (2002) Do Personality Factors Predict Job Satisfaction? Personality and Individual Differences, 33, 1325-1342. http://dx.doi.org/10.1016/S0191-8869(02)00016-8

[61] Matzler, K. and Renzl, B. (2007) Assessing Asymmetric Effects in the Formation of Employee Satisfaction. Tourism Management, 28, 1093-1103.

http://dx.doi.org/10.1016/j.tourman.2006.07.009 
[62] Carter, N.T. and Dalal, D.K. (2010) An Ideal Point Account of the JDI Work Satisfaction Scale. Personality and Individual Differences, 49, 743-748.

http://dx.doi.org/10.1016/j.paid.2010.06.019

[63] Khalilzadeh, J., Del Chiappa, G., Jafari, J. and Borujeni, H.Z. (2013) Methodological Approaches to Job Satisfaction Measurement in Hospitality Firms. International Journal of Contemporary Hospitality Management, 25, 865-882.

http://dx.doi.org/10.1108/IJCHM-05-2012-0067

[64] Papadopoulos, A.S.Y. (2015) School Teachers' Job Satisfaction and Personal Characteristics. International Journal of Educational Management, 29, 73-97. http://dx.doi.org/10.1108/IJEM-05-2013-0081

[65] Alavi, M. and Leidner, D. (2001) Review: Knowledge Management and Knowledge Management Systems: Conceptual Foundations and Research Issues. MIS Quarterly, 25, 107136. http://dx.doi.org/10.2307/3250961

[66] Hajir, J., Obeidat, B., Al-dalahmeh, M. and Masa'deh, R. (2015) The Role of Knowledge Management Infrastructure in Enhancing Innovation at Mobile Telecommunication Companies in Jordan. European Journal of Social Sciences, 50, 313-330.

[67] Masa'deh, R. and Kuk, G. (2009) Antecedents and Intermediaries between Strategic Alignment and Firm Performance. Proceedings of the 2009 Conference of the Academy of Management Annual Meeting (AOM), Chicago, 7-11 August 2009.

[68] Andreassi, J.K., Lawter, L., Brockerhoff, M. and Rutigliano, P. (2012) Job Satisfaction Determinants: A Study across 48 Nations. WCOB Faculty Publications, Paper 220. http://digitalcommons.sacredheart.edu/wcob fac/220

[69] Denison, D.R., Haaland, S. and Goelzer, P. (2004) Corporate Culture and Organizational Effectiveness: Is Asia Different from the Rest of the World? Organizational Dynamics, 33, 98-109. http://dx.doi.org/10.1016/j.orgdyn.2003.11.008

[70] Platsidou, M. and Diamantopoulou, G. (2009) Job Satisfaction of Greek University Professors: Is It Affected by Demographic Factors, Academic Rank and Problem of Higher Education? In: Zarifis, G.K., Ed., Educating the Adult Educators. Quality Provision and Assessment in Europe, Conference Proceedings, ESREA-ReNAdET, Grafima Publications, Thessaloniki, 535-545.

[71] Navaie-Waliser, M., Lincoln, P., Karuturi, M. and Reisch, K. (2004) Increasing Job Satisfaction, Quality Care, and Coordination in Home Health. Journal of Nursing Administration, 34, 88-92. http://dx.doi.org/10.1097/00005110-200402000-00007

[72] Feizi, M. and Farid, S. (2013) Surveying the Impact of Organization Structure on Employee's Job Satisfaction of Agricultural Bank in Ardebil Province. International Journal of Management and Social Sciences Research, 2, 76-80.

[73] Kulik, C. and Perry, E. (2008) When Less Is More: The Effect of Devolution on HR's Strategic Role and Construed Image. Human Resource Management, 47, 541-558. http://dx.doi.org/10.1002/hrm.20231

[74] Willem, A., Buelens, M. and De Jonghe, I. (2005) Impact of Organizational Structure on Nurses' Job Satisfaction: A Questionnaire Survey. International Journal of Nurse Studies, 44, 1011-1020. http://dx.doi.org/10.1016/j.ijnurstu.2006.03.013

[75] Ahmadi, A.A., Momeni, M. and Ahmadi, F. (2013) Required Infrastructures for Implementation of Knowledge Management System in the Masjed Soleyman Oil and Gas Production Company. Interdisciplinary Journal of Contemporary Research in Business, 5, 6072.

[76] Ali, I. and Ali, J. (2005) The Effects of Interaction of Technology, Structure, and Organiza- 
tional Climate on Job Satisfaction. Sunway Academic Journal, 2, 23-32.

[77] Attar, G.A. and Sweis, R.J. (2010) The Relationship between Information Technology Adoption and Job Satisfaction in Contracting Companies in Jordan. Journal of Information Technology in Construction, 15, 44-63.

[78] Ho, C.F., Hsieh, P.H. and Hung, W.H. (2014) Enablers and Processes for Effective Knowledge Management. Industrial Management \& Data Systems, 114, 734-754. http://dx.doi.org/10.1108/IMDS-08-2013-0343

[79] Donate, M.J. and Guadamillas, F. (2011) Organizational Factors to Support Knowledge Management and Innovation. Journal of Knowledge Management, 15, 890-914. http://dx.doi.org/10.1108/13673271111179271

[80] Lai, Y. (2013) The Moderating Effect of Organizational Structure in Knowledge Management for International Ports in Taiwan. International Journal of Computer and Information Technology, 2, 240-246.

[81] Lee, Y.C. and Lee, S.K. (2007) Capabilities, Processes, and Performance of Knowledge Management: A Structural Approach. Human Factors and Ergonomics in Manufacturing, 17, 21-41. http://dx.doi.org/10.1002/hfm.20065

[82] Zaied, A. (2012) An Integrated Knowledge Management Capabilities Framework for Assessing Organizational Performance. International Journal of Information Technology and Computer Science, 4, 1-10. http://dx.doi.org/10.5815/ijitcs.2012.02.01

[83] Tian, J., Nakamori, Y. and Wierzbicki, A.P. (2009) Knowledge Management and Knowledge Creation in Academia: A Study based on Surveys in a Japanese Research University. Journal of Knowledge Management, 13, 76-92. http://dx.doi.org/10.1108/13673270910942718

[84] Kim, S. and Lee, H. (2006) The Impact of Organizational Context and Information Technology on Employee Knowledge-Sharing Capabilities. Public Administration Review, 66, 370-385. http://dx.doi.org/10.1111/j.1540-6210.2006.00595.x

[85] Chong, S.C., Ramachandran, S.D. and Wong, K.Y. (2013) Knowledge Management Practices and Enablers in Public Universities: A Gap Analysis. Campus-Wide Information Systems, 30, 76-94. http://dx.doi.org/10.1108/10650741311306273

[86] Hackman, J.R. and Oldham, G. (1975) Development of the Job Diagnostic Survey. Journal of Applied Psychology, 60, 159-170. http://dx.doi.org/10.1037/h0076546

[87] Bagozzi, R. and Yi, Y. (1988) On the Evaluation of Structural Evaluation Models. Journal of the Academy of Marketing Science, 16, 74-94. http://dx.doi.org/10.1007/BF02723327

[88] Sekaran, U. and Bougie, R. (2013) Research Methods for Business: A Skill-Building Approach. 6th Edition, Wiley, New York.

[89] Creswell, J. (2009) Research Design: Qualitative, Quantitative, and Mixed Methods Approaches. 3rd Edition, Sage Publications, Thousand Oaks.

[90] Pallant, J. (2005) SPSS Survival Manual: A Step Guide to Data Analysis Using SPSS for Windows Version 12. Open University Press, Chicago.

[91] Kambiz, A. and Aslan, A.S. (2014) Investigation on the Impact of Organizational Culture on Organization Innovation. Journal of Management Policies and Practices, 2, 1-10.

[92] Gressgård, L.J., Amundsen, O., Aasen, T.M. and Hansen, K. (2014) Use of Information and Communication Technology to Support Employee-Driven Innovation in Organizations: A Knowledge Management Perspective. Journal of Knowledge Management, 18, 633-650. http://dx.doi.org/10.1108/JKM-01-2014-0013 
Submit or recommend next manuscript to SCIRP and we will provide best service for you:

Accepting pre-submission inquiries through Email, Facebook, LinkedIn, Twitter, etc. A wide selection of journals (inclusive of 9 subjects, more than 200 journals)

Providing 24-hour high-quality service

User-friendly online submission system

Fair and swift peer-review system

Efficient typesetting and proofreading procedure

Display of the result of downloads and visits, as well as the number of cited articles

Maximum dissemination of your research work

Submit your manuscript at: http://papersubmission.scirp.org/

Or contact cn@scirp.org 